JIKAP PGSD: Jurnal Ilmiah Ilmu Kependidikan

Vol,3. No,2. Tahun 2019

e-ISSN: 2597-4440 dan p-ISSN: 2597-4424

This work is licensed under a Creative Commons Attribution

4.0 International License

\title{
Pengaruh Latihan Lompat Dengan Rintangan Dan Meraih Sasaran Di Atas Terhadap Kemampuan Lompat Jauh Gaya Jongkok Pada Siswa Kelas VII 3 SMP Negeri 1 Mare Kabupaten Bone
}

\author{
Yappa \\ Dinas Pendidikan Kabupaten Bone \\ Email: yappa@gmail.com
}

\begin{abstract}
Abstrak. Permasalahan penelitian ini adalah: Apakah ada perbedaan pengaruh latihan lompat dengan rintangan dan meraih sasaran diatas terhadap kemampuan lompat jauh pada siswa Kelas VII 3 SMP Negeri 1 Mare. Tujuan penelitian untuk menyatakan ada dan tidaknya perbedaan pengaruh latihan lompat dengan rintangan dan meraih sasaran di atas. Metode penelitian menggunakan metode eksperimen dengan pola M-S. Populasi penelitian ini siswa Kelas VII 3 SMP Negeri 1 Mare yang berjumlah 24 siswa. Analisis data menggunakan t-test. Hasil penelitian menunjukkan bahwa t-hitung >t-tabel atau 2,4620 > 2,201 dengan taraf signifikan 5\% dengan db 11 berarti ada perbedaan pengaruh yang signifikan antara latihan lompat dengan rintangan dan meraih sasaran diatas terhadap kemampuan lompat jauh pada siswa Kelas VII 3 SMP Negeri 1 Mare. Dari perhitungan mean, menunjukkan bahwa mean kelompok eksperimen 1 lebih besar dari mean kelompok eksperimen 2 (318,67 > 308,17), dengan demikian latihan lompat dengan rintangan lebih baik hasilnya dibandingkan dengan latihan meraih sasaran di atas. Melihat hasil penelitian, disarankan kepada guru Penjas dan pelatih untuk meningkatkan kemampuan lompat jauh gaya jongkok dapat melakukan latihan lompat dengan rintangan
\end{abstract}

Kata kunci : Latihan Lompat, Kemampuan Lompat Jauh Gaya Jongkok

\begin{abstract}
The problem of this research is: Is there a difference in the effects of exercise jumping obstacles and achieve goals on the ability of the long jump at the Class VII student SMP Negeri 1 Mare. The research objective to declare the presence and absence difference in the effects of exercise jumping obstacles and achieve the above targets. The research method uses an experimental method with the M-S pattern. This study population Class VII student SMP Negeri 1 Mare amounting to 24 students. The research instrument used was the squat style long jump test. Data analysis using the t-test. The results showed that $t$ count $>t-$ table or $2.4620>2.201$ with a significant level of $5 \%$ to $11 \mathrm{~dB}$ means that there is a significant difference between the exercise jumping obstacles and achieve goals on the ability of the long jump at Seventh Grade 3 student of SMP Negeri 1 Mare. From the calculation of the means, indicating that the first experimental group mean is greater than the mean of the experimental group 2 (318.67> 308.17), thereby exercise hurdle jump with better results compared with the exercise achieve the above targets. To see the results, it is suggested to Penjas teachers and trainers to improve the long jump ability can squat exercise style jump with the hurdle.
\end{abstract}

Keywords: Jump Training, Squat Style Long Jump Ability 


\section{PENDAHULUAN}

Dalam kehidupan modern manusia tidak dapat dipisahkan dari olahraga, baik sebagai arena adu prestasi maupun sebagai kebutuhan untuk menjaga kondisi tubuh agar tetap sehat. Olahraga mempunyai peranan yang penting dalam kehidupan manusia. Melalui olahraga dapat dibentuk manusia yang sehat jasmani, rohani serta mempunyai kepribadian, disiplin, sportifitas yang tinggi sehingga pada akhirnya akan terbentuk manusia yang berkualitas. Suatu kenyataan yang bisa diamati dalam dunia olahraga, menunjukkan kecenderungan adanya peningkatan prestasi olahraga yang pesat dari waktu kewaktu baik ditingkat daerah, nasional maupun internasional. Hal ini dapat dilihat dari pemecahanpemecahan rekor yang terus dilakukan pada cabang olahraga tertentu, penampilan tehnik yang efektif dan efisien dengan ditunjang oleh kondisi fisik yang baik.

Dengan adanya kecendrungan prestasi yang meningkat, maka untuk berpartisipasi dan bersaing antar atlet dalam kegiatan olahraga prestasi harus dikembangkan kualitas fisik, tehnik, psikologi dan sosial yang dituntut oleh cabang olahraga tertentu. Oleh karena itu melalui pengembangan dan pembinaan di masyarakat, olahraga wajib diajarkan di sekolah-sekolah dari sekolah tingkat dasar, sekolah tingkat pertama sampai dengan sekolah tingkat menengah.

Olahraga atletik merupakan salah satu mata pelajaran yang wajib diajarkan pada siswa di SMP sesuai dengan materi kurikulum 2006 standar kompetensi Sekolah Dasar dan Madrasah Ibtidaiyah. Menurut Aip Syarifuddin dan Muhadi (1992/1993: 59) atletik adalah salah satu cabang olahraga yang tertua yang dilakukan oleh manusia sejak jaman Yunani Kuno sampai dewasa ini. Dalam mata pelajaran atletik yang dipelajari adalah gerakan dasar manusia di dalam kehidupan sehari-hari, yaitu berjalan, berlari, melompat dan melempar. Selain itu dalam kejuaraan atletik ada beberapa nomor yang diperlombakan antaranya adalah nomor lari, jalan cepat, nomor lompat dan nomor lempar. Khusus untuk nomor lompat yang diperlombakan baik yang bersifat nasional maupun internasional terdiri dari nomor : lompat jauh, lompat tinggi, lompat jangkit dan lompat tinggi galah.

Keempat nomor lompat tersebut yang akan dibahas lebih lanjut adalah pada nomor lompat jauh. Lompat jauh adalah salah satu nomor lompat dari cabang olahraga atletik. Dalam perlombaan lompat jauh seorang pelompat akan bertumpu pada balok tumpuan sekuatkuatnya dan untuk mendarat di bak lompat sejauhjauhnya. Menurut Aip Syarifuddin (1992 : 90) lompat jauh adalah suatu bentuk gerakan melompat mengangkat kaki ke atas, ke depan dalam upaya membawa titik berat badan selama mungkin di udara (melayang di udara) yang dilakukan dengan cepat dan dengan jalan melakukan tolakan pada satu kaki untuk mancapai jarak yang sejauh -jauhnya. Karena lompat jauh termasuk nomor lompat yang diperlombakan, maka diperlukan metode latihan yang tepat untuk meningkatkan prestasi. Untuk mencapai prestasi yang baik di dalam lompat jauh menurut Aip Syarifuddin (1992 : 90), selain si pelompat harus memiliki kekuatan, daya ledak, kecepatan, ketepatan, kelentukan dan koordinasi gerak, juga harus memahami dan menguasai tehnik untuk melakukan gerakan lompat jauh tersebut serta dapat melakukannya dengan cepat, tepat, luwes dan lancar. Tehnik untuk lompat jauh yang benar perlu memperhatikan unsur-unsur: awalan, tolakan, sikap badan di udara (melayang) dan mendarat. Menurut Yoyo Bahagia dkk (1999 / 2000 : 16) keempat unsur ini merupakan satu kesatuan, yaitu urutan gerakan lompat yang tidak terputus.

Dalam lompat jauh terdapat beberapa macam gaya atau sikap badan pada saat melayang di udara. Soegito dkk (1994 : 143) menyebutkan ada tiga cara sikap melayang yaitu: 1) gaya jongkok (waktu melayang bersikap jongkok), 2) gaya lenting (waktu di udara badan dilentingkan), dan 3) gaya jalan di udara (waktu melayang kaki bergerak seolah-olah berjalan di udara). Gaya lompat jauh yang paling sederhana untuk diajarkan pada pemula seperti siswa di SMP adalah lompat jauh gaya jongkok. Tehnik lompat jauh gaya jongkok termasuk yang paling sederhana di banding dengan gaya yang lain.

Untuk mencapai prestasi yang baik di dalam lompat jauh perlu didukung dengan latihan yang baik melalui pendekatanpendekatan ilmiah dengan melibatkan berbagai ilmu pengetahuan. Kaitannya dengan latihan untuk mencapai prestasi ada beberapa unsur yang perlu diperhatikan dan ditingkatkan. Unsur tersebut menurut M. Sajoto (1988 : 15) diantaranya adalah: 1) unsur fisik yang lebih popular dengan kondisi fisik, 2) unsur tehnik, 3) unsur mental, 4) unsur kematangan juara. Dari keempat unsur tersebut, ialah satu unsur 
yang merupakan faktor utama yaitu kondisi fisik, seperti pendapat dari Depdiknas (2000 : 101) bahwa salah satu unsur atau faktor penting untuk meraih suatu prestasi dalam olahraga adalah kondisi fisik, disamping penguasaan tehnik, taktik dan kemampuan mental.

Kondisi fisik menurut M. Sajoto (1988 : 16) adalah satu kesatuan yang utuh dari komponen-komponen yang tidak dapat dipisahkan begitu saja, baik peningkatan maupun pemeliharaannya. Artinya bahwa di dalam usaha peningkatan kondisi fisik maka seluruh komponen tersebut harus dikembangkan, walaupun disana sini dilakukan dengan system prioritas sesuai keadaan atau status tiap komponen itu dan untuk keperluan apa keadaan atau status yang dibutuhkan tersebut. Komponen yang dimaksud menurut M. Sajoto (1988 : 16) adalah sebagai berikut : 1. Kekuatan; 2. Daya tahan; 3. Daya ledak; 4. Kecepatan; 5. Daya lentur; 6. Kelincahan; 7. Koordinasi; 8. Keseimbangan; 9. Ketepatan dan 10. Reaksi.

Dari beberapa komponen kondisi fisik tersebut, menurut Aip Syarifuddin (1992 : 93) komponen yang sangat besar pengaruhnya terhadap hasil lompatan pada lompat jauh adalah kekuatan otot tungkai yang meliputi : kecepatan yaitu pada awalan dan kekuatan yaitu pada tolakan. Perpaduan antara kecepatan dan kekuatan dinamakan power atau daya otot (M. Sajoto, 1988 : 12). Usaha untuk meningkatkan power dibutuhkan latihan yang disesuaikan dengan kemampuan atlet, sebab atlet dari masing-masing cabang baik dari cabang yang sama dan bahkan dari cabang yang berbeda yang memiliki kemampuan yang berlainan. Dengan demikian perlu dicari bentuk latihan yang tepat dan efektif untukmeningkatkan power ototnya terutama pada kemampuan melompat adalah kekuatan otot-otot pada tungkai.

Menurut Aip Syarifuddin dan Muhadi (1992/1993 : 49, 50) latihan pembentukan daya ledak anak usia SD dapat dilakukan dengan jalan latihan lompat jauh tanpa awalan, lompat setinggi-tingginya meraih sesuatu benda yang tergantung di atas, atau meraih pada dinding dan lompat berjongkok (squat jump). Dikatan oleh J. Matakupan (1996 : 56) bahwa aktivitas bermain pada anak yang dilakukan pada proses pendidikan jasmani akan sangat penting dalam masa pertumbuhan anak, dasar gerak akan menjadi lebih baik karena meningkatnya kekuatan otot, kelentukan, daya tahan otot setempat dan daya tahan cardiovaskuler yang semakin menjadi baik, selain itu akan menjadi panjang dan besarnya otot-otot, fungsi organ tubuh menjadi baik, sehingga dapat dikatakan bahwa terjadi pertumbuhan dan perkembangan yang lebih baik. Bentuk latihan lain yang dapat meningkatkan kekuatan otot kaki menurut Carr (2000 : 120) adalah dengan melompat rintangan rendah dan memyundul bola. Sedangkan menurut Gunter Bernhard (1993 : 86) bentuk-bentuk permainan dan latihan untuk melatih melompat pada lompat jauh yaitu loncatan- loncatan dengan menyentuh suatu penentu selama mungkin memegang teguh sikap tubuh bagian atas yang tegak, penentu arah selalu diambil dari tempat pendaratan.

Untuk merangsang agar siswa melakukan lompatan yang cukup melambung, perlu dipasang tali atau batas melintang di atas tepi bak pasir, dengan ketinggian sekitar $75 \mathrm{~cm}$, jarak antara balok tumpu dengan tali/bilah .sekitar 1-2 meter untuk disesuaikan dengan kemampuan (Tamsir Riyadi, 1985 : 103). Beberapa metode latihan lompat menurut beberapa ahli dapat dilakukan dengan: 1) Melompat di atas serangkaian rintangan rendah, cara melakukannya masingmasing peserta melompat atau melambung di atas serangkaian rintangan yang rendah , tangan digerakkan di atas dan paha kaki yang memimpin digerakkan keatas pada setiap lompatan (Gerry A. Carr, 1997 : 141), dan 2) Meraih bola yang digantung atau meraih sasaran di atas, pelaksanaannya : gantungkan bola dengan tali, kira-kira setinggi $30 \mathrm{~cm}$ hingga $60 \mathrm{~cm}$ di atas kepala, peserta menggunakan run-up 3 hingga 5 langkah, masing-masing siswa melompat untuk menyentuh bola, dengan menggunakan take-off satu kaki. Jika mereka menyentuh bola dengan baik, mereka berpindah ke bola yang lain (Gunter Bernhard, 1993 : 86).

Latihan-latiahan tersebut diberikan pada anak dengan program latihan memakai beban berat badannya sendiri. Seperti yang dikatakan M. Sajoto (1988 : 42) beban yang digunakan dapat berupa berat badan sendiri, dengan berteman, bola karet, tali elastis, dumble, burble, latihan mendorong dan menahan alat permanen seperti latihan isometric. Dengan adanya berbagai macam bentukbentuk latihan lompat jauh yang tujuannya untuk memacu atau merangsang tolakan kaki agar kuat sehingga menghasilkan lompatan melambung tinggi.

Dalam penelitian ini dipilih dua jenis bentuk latihan yaitu latihan lompat dengan 
rintangan rendah dan lompat setinggitingginya meraih suatu benda. Latihan ini pada intinya bertujuan untuk memacu dan merangsang tolakan kaki agar kuat sehingga menghasilkan lompatan melambung tinggi. Kedua bentuk latihan tersebut belum diketahui dengan pasti, mana yang lebih efektif dalam meningkatkan prestasi lompat jauh. Untuk mengetahui bentuk latihan yang dapat memberikan pengaruh yang lebih baik, maka perlu dilakukan penelitian.

Berdasarkan uraian tersebut, penulis akan melakukan penelitian eksperimen dengan judul : Pengaruh Latihan Lompat dengan Rintangan dan Meraih Sasaran Di atas Terhadap Kemampuan Lompat Jauh pada Siswa Kelas VII 3 SMP Negeri 1 Mare Kabupaten Bone, dengan alasan pemilihan judul adalah :

1. Latihan lompat dengan rintangan dan lompat meraih sasaran di atas merupakan bentuk latihan yang sederhana, mudah, tidak membahayakan dan dapat digunakan sebagai metode pembelajaran pada siswa SMA.

2. Latihan lompat dengan rintangan dan lompat meraih sasaran di atas dapat merangsang anak untuk melakukan lompatan yang cukup tinggi, lompatan yang melambung tinggi sangat dibutuhkan untuk melompat, sehingga mempengaruhi jauhnya lompatan.

\section{METODE PENELITIAN}

Metode penelitian merupakan syarat mutlak dalam suatu penelitian. Penggunaan metode penelitian dalam suatu penelitian harus tepat dan mengarah pada tujuan penelitian, serta dapat dipertanggung jawabkan secara ilmiah. Maksudnya adalah untuk menjaga agar pengetahuan yang dicapai dari suatu penelitian memberikan arah yang tepat guna tercapainya tujuan penelitian.

Populasi adalah sejumlah penduduk atau individu yang paling sedikit mempunyai satu sifat yang sama (Hadi, 2000: 220). Sedangkan menurut Arikunto (1998: 115), populasi adalah keseluruhan subjek penelitian. Dari pendapat tersebut di atas dapat disimpulkan bahwa populasi adalah seluruh individu yang akan dijadikan subjek penelitian dan keseluruhan individu itu paling sedikit harus memiliki suatu sifat yang sama.

Populasi dalam penelitian ini adalah siswa putra Kelas VII 3 SMP Negeri 1 Mare yang berjumlah 24 orang siswa putra. Adapun alasan pengambilan populasi adalah :
1. Mereka sama-sama dalam satu sekolah, yaitu siswa putra Kelas VII 3 SMP Negeri 1 Mare

2. Mempunyai jenis kelamin yang sama, yaitu laki-laki

Berdasarkan uraian di atas, maka populasi yang diambil telah memenuhi syarat, dimana suatu populasi harus memiliki minimal satu sifat yang sama, berarti populasi ini dapat diterima.

Sampel adalah sebagian atau wakil populasi yang diteliti (Arikunto, 1998: 117). Pendapat lain, Hadi (2000: 221), menjelaskan bahwa sampel adalah sebagian dari populasi yang diselidiki.

Pedoman dalam pengambilan jumlah sampel ini, penulis mengacu pada pendapat Arikunto (1998: 120) yaitu hanya untuk sekedar ancer-ancer apabila subyek kurang dari 100 sebaiknya diambil semua sehingga penelitiannya merupakan penelitian populasi. Selanjutnya jika subyek besar dapat diambil antara 10$15 \%$, atau $20-25 \%$ atau lebih, tergantung setidak-tidaknya dari kemampuan peneliti dilihat dari segi waktu, dana, dan tenaga.

Sampel dalam penelitian ini adalah seluruh siswa putra Kelas VII 3 SMP Negeri 1 Mare, yang berjumlah 24 anak. Subyek yang diteliti sejumlah 24 orang siswa maka ditetapkan sebagai sampel semua karena jumlah sampel atau subyeknya kurang dari 100 orang. Oleh sebab itu dalam penentuan atau pengambilan sampel menggunakan teknik Total Sampling, yaitu mengikutkan semua anggota populasi sebagai sampel penelitian.

Variabel adalah gejala yang bervariasi dan menjadi objek penelitian, atau apa yang menjadi titik perhatian suatu penelitian (Arikunto, 1998: 99). Dalam penelitian ini terdapat dua variabel, yaitu variabel bebas dan variabel terikat. Variable bebas dalam penelitian ini yaitu latihan lompat dengan rintangan dan latihan lompat meraih sasaran diatas. Sedangkan variable terikatnya adalah kemampuan lompat jauh.

\section{Metode Penelitian}

Agar penelitian ini dapat memperoleh hasil yang baik dan sesuai dengan harapan, maka metode penelitian yang dipergunakan dalam penelitian ini adalah metode eksperimen. Dasar penggunaan metode eksperimen adalah kegiatan percobaan yang diawali dengan memberikan perlakuan terhadap subjek dan diakhiri dengan tes untuk menguji seberapa jauh akibat dari perlakuan yang diberikan. Jadi 
metode eksperimen merupakan metode yang paling tepat untuk menyelidiki hubungan sebab akibat.

\section{Rancangan Penelitian}

Pola eksperimen yang digunakan dalam penelitian ini adalah Matchced by Subject Design atau disingkat dengan Pola M-S, yang mengandung suatu pengertian seperti dikatakan oleh Sutrisno Hadi (1973 : 453) bahwa pola M-S matching dilakukan terhadap subjek demi subjek. Hakekat Subjek Macthing adalah sedemikian rupa sehingga pemisahan pasangan-pasangan subjek masing-masing kelompok eksperimen 1 dan kelompok eksperimen 2 secara otomatis akan menseimbangkan kedua kelompok itu. Rancangan penelitian dapat digambarkan pada tabel 3 berikut ini.

Tabel 3: Rancangan penelitian

\begin{tabular}{clll}
\hline KLP & Pre-test & Treatme & Post-test (test \\
\hline Eksperi & Lompa & Latihan & Lompat jauh \\
men 1 & t jauh & lompat & jongkok (X2) \\
Eksperi & gaya & dengan & Lompat jauh \\
men 2 & jongko & rintang & jongkok(X2) \\
& k (X1) & an & \\
& Lompa & Latihan & \\
& t jauh & lompat & \\
& gaya & meraih & \\
& jongko & sasaran & \\
k (X1) & diatas & \\
\hline
\end{tabular}

a. Pelaksanaan Penelitian

Penelitian ini dilaksanakan selama 6 minggu, yaitu mulai tanggal 13 Januari 2017 sampai dengan 24 Pebruari 2017. Penelitian ini diawali dengan pre test pada tanggal 13 Januari 2017 dan hari latihan mulai tanggal 18 Januari 2017 sampai dengan 22 Pebruari 2017. Post test dilaksanakan pada tanggal 24 Pebruari 2017. Penelitian ini dilaksanakan tiga kali seminggu tiap hari Selasa, Kamis dan Sabtu. Dengan pelaksanaan tiap sore pukul 15.00-16.30 WIB. Tes tersebut terbagi dalam tiga kegiatan: 1) Tes awal, 2) Perlakuan, 3) Tes akhir

1) Pre Test atau Tes Awal

Tes awal dilaksanakan dilapangan / halaman olahraga SMP Negeri 1 Mare. Tes yang dilakukan dalam penelitian ini adalah lompat jauh yang disesuaikan dengan buku peraturan perlombaan atletik dari PASI. Sebelum tes awal dimulai, siswa diberi penjelasan mengenai pelaksanaan tes lompat jauh. Sesudah diberi penjelasan baru dilaksanakan tes awal. Tes awal dilaksanakan pada hari Selasa tanggal 13 Januari 2017 pukul 08.00 WIB sampai dengan selesai dilapangan / halaman SMP Negeri 1 Mare Kecamatan Ulaweng, .

2) Perlakuan

Penelitian ini dilaksanakan selama 6 minggu, setiap minggu 3 kali pertemuan mulai tanggal 18 Januari 2017 sampai 22 Pebruari 2017 dengan demikian penelitian ini dilaksanakan selama 16 kali pertemuan. Sedangkan setiap pertemuan dilaksanakan selama \pm 90 menit, dengan pengaturan waktu yaitu 10 menit untuk pemanasan, 70 menit latihan inti dan 10 menit untuk penenangan.

Waktu kegiatan latihan dilaksanakan pada hari Selasa, Kamis dan Sabtu dimulai pukul 15.00 - 16.30 WIB. Materi latihan pada kelompok eksperimen 1 adalah latihan lompat dengan rintangan dan kelompok eksperimen 2 adalah latihan lompat meraih sasaran. Untuk penyajian materi disesuaikan dengan alokasi waktu yang tersedia. Sedangkan mengenai pengaturan waktu latihan adalah sebagai berikut.

a) Pemanasan

Pemanasan diberikan pada siswa secukupnya dengan tujuan untuk persiapan fisik siswa sebelum melakukan latihan inti. Latihan ini sangat penting untuk tubuh dan menghindari resiko terjadinya cedera otot maupun sendi, mengadakan perubahan dalam fungsi organ tubuh guna menghadapi fisik yang lebih berat (Tohar, 2008 : 4). Latihan yang merupakan kegiatan pemanasan dalam penelitian ini meliputi keliling lapangan, senam kelentukan dan senam khusus yang bertujuan untuk menyiapkan siswa pada materi latihan yang akan dilakukan.

b) Latihan Inti

Latihan inti dilaksanakan sesuai dengan program latihan materi diberikan sesuai dengan jadwal latihan. Setiap kelompok berlatih lompat sesuai dengan kelompoknya. Kelompok eksperimen 1 berlatih lompat dengan rintangan, sedangkan kelompok eksperimen 2 berlatih lompat meraih sasaran diatas. Setelah melakukan latihan sesuai dengan kelompoknya masing-masing kemudian latihan lompat jauh gaya jongkok
c) Penenangan
Penenangan dilaksanakan selama 10 menit dan hal ini bertujuan untuk memulihkan kembali kondisi badan sesudah menerima materi latihan, dengan demikian keadaan tubuh akan pulih secara sempurna seperti semula. Adapun gerakan yang digunakan untuk penenangan bisa melakukan gerakan-gerakan 
stretching kembali. Selanjutnya bisa diberi penjelasan atau koreksi secara keseluruhan selama jalannya latihan, kesan dan pesan untuk membangkitkan motivasi latihan berdoa dan dibubarkan.

3) Post Test atau Tes Akhir

Setelah program latihan dilaksanakan selama 16 kali pertemuan, pada tanggal 24 Pebruari 2017 dilaksanakan tes akhir yang pelaksanaannya sama dengan tes awal. Adapun tujuan dilaksanakannya tes akhir adalah untuk mengetahui hasil yang dicapai oleh siswa baik dari kelompok eksperimen 1 dan kelompok eksperimen 2 setelah mengikuti program latihan.

b. Tempat Penelitian

Tempat penelitian yang digunakan adalah lapangan olahraga SMP Negeri 1 Mare, .

c. Alat dan Perlengkapan Penelitian

Alat dan perlengkapan penelitian adalah faktor penting yang sangat membantu kelancaran pelaksanaan penelitian dan untuk mendapatkan data yang sesuai dengan apa yang diinginkan. Alat dan perlengkapan tersebut terdiri dari : 1) Bak lompat jauh, 2) Roll meter, 3) Bendera kecil, 4) Cangkul, 5) Alat Tulis / blangko penilaian.

d. Tenaga Pembantu

Demi kelancaran jalannya penelitian ini, peneliti dibantu oleh beberapa tenaga guru Pendidikan Jasmani SMP Negeri 1 Mare dan siswa Kelas VII 3 yang bertugas menyiapkan sarana latihan dan sebagai pembantu dalam pelaksanaan tes awal dan tes akhir.

1. Instrumen Tes

Instrumen adalah alat pada waktu peneliti menggunakan suatu metode (Suharsimi Arikunto, 1998 : 137). Dalam penelitian ini metode yang digunakan adalah instrumen tes. Tes yang diperlukan dalam penelitian ini adalah tes lompat jauh. Tujuan tes lompat jauh ini adalah untuk mengetahui hasil lompatan.

2. Program Latihan

Program latihan adalah jumlah pertemuan yang dilaksanakan selama penelitian berlangsung. Program latihan ini berlangsung 16 kali pertemuan perlakuan (treatment) ditambah dua pertemuan untuk tes awal dan tes akhir. Jumlah pertemuan latihan tiga kali dalam seminggu, sehingga waktu yang dipergunakan ada enam minggu. Hal ini menurut De Lorme dan Watkin yang dikutip oleh M. Sajoto (1988 : 48), program latihan yang dilakukan empat kali seminggu selama enam minggu cukup efektif, namun rupanya pelatih cenderung melaksanakan latihan setiap minggu tiga kali agar tidak terjadi kelelahan yang kronis dengan lama latihan enam minggu atau lebih.

Teknik pengambilan data dilaksanakan dengan tes dan pengukuran. Nurhasan (2001: 24 dan 25) menjelaskan tes adalah alat ukur yang dapat digunakan untuk memperoleh data yang obyektif tentang hasil belajar siswa. Sedangkan pengukuran adalah proses pengumpulan data atau informasi dari suatu obyek tertentu dan dalam proses pengukuran diperlukan suatu alat ukur. Cirri khas dari hasil pengukuran yakni dinyatakan dalam skor kuantitatif yang dapat diolah secara statistik. Melalui pengukuran kita akan memperoleh informasi yang obyektif sehingga kita dapat menentukan kemampuan atau prestasi seseorang pada saat tertentu.

Tes dan pengukuran dalam penelitian ini dilaksanakan untuk mendapatkan data tentang hasil lompat jauh gaya jongkok yang dilaksanakan dua kali yaitu pretest dan post-test. Hasil tes dicatat dalam satuan centimeter.

Menurut Sutrisno Hadi (1973 : 455) analisis terhadap hasil-hasil eksperimen yang didasarkan atas subject matching selalu menggunkan t-test pada correlated sampel. Dengan demikian untuk pengetesan signifikansi dengan menggunakan ttest dengan rumus pendek (short methode). Rumus ini banyak digunakan dalam penelitian eksperimen karena efektif dan efisien seperti yang dikemukakan Sutrisno Hadi (1973 : 458), rumus pendek adalah rumus yang serba guna dan efisien, rumus ini dapat dipersiapkam untuk penyelidikan eksperimen yang menggunakan matching subjek. Untuk analisa data diperlukan suatu rumus t-test, sebagai berikut

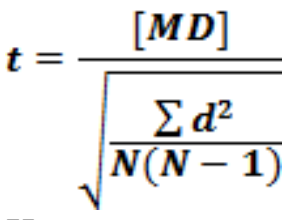

Keterangan :
$\mathrm{T}$ : nilai perbedaan
$\mathrm{N} \quad$ : jumlah subjek
M : rata-rata selisih antara X1 dan X2
D : penyimpangan (selisih) antara X1 dan X2 


\section{HASIL DAN PEMBAHASAN}

Untuk mencari hasil perbedaan latihan lompat dengan rintangan dan lompat meraih sasaran di atas dapat dilihat pada hasil analisis $t$-test seperti tercantum pada Tabel 4 berikut ini :

Tabel 4. Rangkuman Hasil Perhitungan Statistik KLP Mean t-hitung t-tabel Keteranga

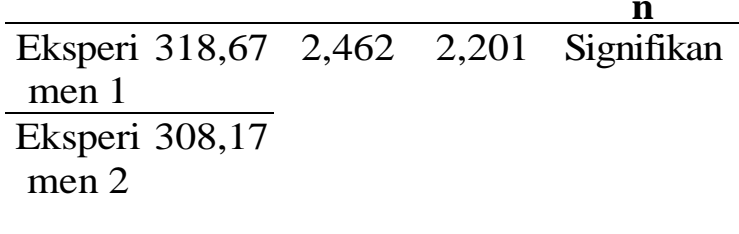

Dari hasil perhitungan statistik diperoleh nilai t-hitung 2,462 kemudian t-tabel dengan $\mathrm{db}$ 11 dan taraf signifikan 5\% diperoleh hasil 2,201, dengan demikian thitung lebih besar dari pada t-tabel yaitu $2,462>2,201$, maka hipotesis dalam penelitian ini yang menyatakan ada perbedaan pengaruh antara latihan lompat dengan rintangan dan lompat meraih sasaran di atas terhadap kemampuan lompat jauh pada siswa putra Kelas VII 3 SMP Negeri 1 Mare diterima.

Dari hasil analisis data ditemukan adanya perbedaan yang signifikan, maka dilakukan uji lanjut untuk mengetahui metode latihan mana yang lebih baik pengaruhnya antara latihan lompat dengan rintangan dan lompat meraih sasaran di atas terhadap kemampuan lompat jauh dilakukan uji perbandingan mean. Diketahui mean kelompok eksperimen $1=318,67$ dan mean kelompok eksperimen $2=308,17$, berarti $\mathrm{MXe} 1>\mathrm{MX}_{\mathrm{e}} 2$, maka latihan lompat dengan rintangan lebih baik pengaruhnya dari pada latihan lompat dengan meraih sasaran di atas pada siswa Kelas VII 3 SMP Negeri 1 Mare.

Hasil penelitian antara latihan lompat dengan rintangan dan latihan lompat meraih sasaran diatas terhadap kemampuan lompat jauh gaya jongkok menunjukkan adanmya pengaruh yang berarti. Ternyata meskipun menurut teori masing-masing mempunyai kelebihan, secara analisis gerakan kedua bentuk latihan dalam penelitian ini adalah ketinggian lompatan yang dihasilkan pada latihan lompat dengan rintangan lebih tinggi apabila dibandingkan dengan latihan lompat meraih sasaran diatas perbedaan hasil latihan ini terutama pada lompatan yang melambung sehingga jarak yang dihasilkan lebih baik.

Hasil perbandingan antara latihan lompat dengan rintangan dan latihan lompat meraih sasaran diatas terhadap kemampuan daya ledak otot tungkai yang digunakan untuk melakukan tolakan lompat jauh menunjukkan sama-sama menghasilkan lompatan yang tinggi, akan tetapi pada latihan lompat dengan rintangan, lompatan yang dihasilkan melambung tinggi dan dilakukan dengan cepat sehingga hasil lompatannya lebih jauh, sedangkan pada lompat meraih sasaran diatas lompatan yang dihasilkan kurang melambung tinggi dan dilakukan lebih lambat sehingga jarak yang dihasilkan kurang jauh.

Pada latihan lompat dengan rintangan punya satu kelebihan yaitu adanya irama gerakan melambung tinggi keatas. Gerakan pada waktu melayang dipengaruhi oleh suatu kekuatan tarikan yang disebut daya tarik bumi

(Aip Syarifuddin : 1992). Daya tarik bumi tersebut bertitik tolak pada suatu titik yang disebut titik berat badan. Titik berat badan letaknya kira-kira pada pinggang sedikit dibawah pusar. Hal ini sesuai dengan gerakan melayang pada latihan lompat dengan rintangan. Sehingga pada latihan ini dapat membentuk gerakan cukup efektif dan efisien didalam hal pemakaian ruang gerak, waktu dan tenaga yang dihasilkan serta perbaikan kemampuan gerakan pada lompat jauh gaya jongkok. Sedangkan latihan melompat meraih sasaran diatas irama gerakan tercurahkan pada konsentrasi gerakan meraih sasaran, sehingga gerakan yang dihasilkan berupa lompatan keatas saja (vertikal) tanpa ada dorongan usaha melompat kedepan sejauh jauhnya, sehingga hasil lompatan kurang maksimal. Pemberian latihan selama 16 kali pertemuan berdasarkan hasil penelitian di atas berarti hipotesis penelitian ini dapat diterima dan terbukti kebenarannya. Dengan demikian apa yang telah dilakukan dalam penelitian ini mulai dari penelitian populasi, pengambilan sampel, variabel, tes awal, program latihan, tes akhir dan metodologi penelitian sudah benar dan terbukti.

\section{SIMPULAN DAN SARAN}

Berdasakan hasil penelitian dan pembahasan, maka peneliti dapat menyimpulkan bahwa :

1. Ada perbedaan pengaruh antara latihan 
melompati rintangan dan meraih sasaran di atas terhadap kemampuan lompat jauh pada siswa Kelas VII 3 SMP Negeri 1 Mare.

2. Latihan lompat dengan rintangan lebih baik pengaruhnya dari pada latihan lompat meraih sasaran di atas terhadap kemampuan lompat jauh pada siswa putra Kelas VII 3 SMP Negeri 1 Mare.

Berdasarkan pada hasil akhir dari penelitian ini maka dapat diberikan saran sebagai berikut :

1. Bagi Guru Penjaskes dan pelatih untuk memperoleh hasil yang lebih baik dalam latihan daya ledak otot tungkai disarankan menggunakan bentuk latihan lompat dengan rintangan, karena sudah diuji bahwa latihan lompat dengan rintangan mempunyai pengaruh lebih baik dari pada latihan lompat meraih sasaran di atas terhadap kemampuan lompat jauh gaya jongkok.

2. Untuk Peneliti yang berminat dapat meneliti ulang dan hasil penelitian bisa digunakan sebagai pembanding.

\section{DAFTAR RUJUKAN}

Arikunto, Suharsimi. 1998. Prosedur Penelitian. Yogyakarta: Rineka Cipta.

Bernhard, G. 1993. Atletik Prinsip Dasar Latihan Loncat Tinggi, Jauh, Jangkit dan Loncat Galah. Terjemahan dari String Trainning voor. Djeugd. Semarang: Dahara Prize.

Carr, Gerry. 2000. Atletik (Edisi Terjemahan). Jakarta: PT. Raja Grafindo Persada.

Depdiknas. 2000. Pedoman dan Modal Pelatihan Kesehatan Olah Raga Bagi Pelatih Olahragawan Pelajar. Jakarta.

Depdikbud. 2008. Kurikulum 2008 Standar Kompetensi SD dan MI. Jakarta: Dharma Bhakti.

Engkos, Kosasih. 1985. Olahraga Tehnik dan Program Latihan. Jakarta: Akademika Pressindo.

Hadi, Rubianto. 2003. Ilmu Kepelatihan Dasar. Semarang: FIK UNNES.

Hadi, Sutrisno. 2000. Statistik II. Yogyakarta: Rineka Cipta.

Harsono. 1982. Ilmu Coaching. Jakarta: KONI Pusat. J. Matakupan. 1996. Teori Bermain. Jakarta: Depdikbud KONI. 2000. Panduan Kepelatihan. Jakarta: KONI.
Nurhasan. 2001. Tes dan Pengukuran dalam Pendidikan Jasmani. Jakarta: Depdiknas.

Poerwodarminto. 1984. Kamus Umum Bahasa Indonesia. Jakarta: Depdikbud.

Riyadi, Andi.Tamsir. 1985. Petunjuk Atletik. Yogyakarta: FPOK IKIP Yogyakarta

Tohar. 2008. Ilmu Kepelatihan Lanjut. Semarang: FIK UNNES

Sajoto, M.. 1988. Peningkatan dan Pembinaan Kekuatan Kondisi Fisik dalam Olahraga. Semarang: Dahara Prize.

Soedarminto dan Soeparman. 1993. Materi Pokok Kinesiologi. Jakarta.

Sugito dkk. 1994. Pendidikan Atletik. Jakarta: Depdikbud.

Suharno. HP. 1986. Ilmu Kepelatihan Olahraga. Yogyakarta: FPOK IKIP Yogyakarta.

Syarifuddin, Aip. 1992. Atletik. Jakarta: Depdikbud.

Syarifuddin, Aip dan Muhadi. Pendidikan Jasmani dan Kesehatan. Jakarta: Depdikbud.

Yusuf, Adisasmita. 1992. Olahraga Pilihan Atletik. Jakarta: Dekdikbud. 